\title{
A simple RP-HPLC method for determination of nitisinone in pharmaceuticals
}

\author{
Zana Mustafa $^{1^{*}}$, Zorica Arsova-Sarafinovska ${ }^{1}$, Maya Shishovska ${ }^{1}$, \\ Aleksandra Grozdanova ${ }^{2}$ \\ ${ }^{1}$ Institute of Public Health of the Republic of North Macedonia, St. 50 Division No. 6, \\ 1000 Skopje, Republic of North Macedonia \\ ${ }^{2}$ Institute of Pharmaceutical chemistry, Faculty of Pharmacy, \\ Ss. Cyril and Methodius University, Majka Tereza 47, 1000 Skopje, \\ Republic of North Macedonia
}

Received: October 2019; Accepted: December 2019

\begin{abstract}
Nitisinone is a reversible inhibitor of 4-hydroxyphenylpyruvate dioxygenase and an active substance in the orphan drug used for the treatment of hereditary tyrosinemia type I, a rare genetic disease caused by mutations in the gene for the enzyme fumarylacetoacetase. The aim of our study was to develop a simple and accurate RP-HPLC method with UV detection for routine determination of nitisinone in commercially available pharmaceutical forms. The chromatographic separation was achieved on a reversed-phase column Purospher STAR $^{\circledR}$ RP-8 end-capped $(150$ x $4.6 \mathrm{~mm}$ i.d., particle size $5 \mu \mathrm{m})$, with a mobile phase consisted of a mixture of acetonitrile and water acidified with o-phosphoric acid with $\mathrm{pH}$ adjusted to 3.0, 65:35 ( V/V), filtered through $0.45 \mu \mathrm{m}$ nylon filter. The flow rate was kept at 1 $\mathrm{mL} / \mathrm{min}$. A diode array detector measured the UV absorbance at $272 \mathrm{~nm}$. The injection volume was $10 \mu \mathrm{L}$. The method was validated by a determination of system suitability, specificity, linearity, range, accuracy, precision, detection limit and quantitation limit. Then, the method was applied for determination of nitisinon in commercially available capsules. The proposed RP-HPLC method allows a simple, accurate, precise and rapid determination of nitisinone in pharmaceuticals. The advantages of the method include simple sample treatment, good precision (RSD less than 2\%) and high recovery (greater than 99\%). The method could be recommended for routine analysis in quality control laboratories, in stability studies as well as for the evaluation of potentially counterfeit capsules containing nitisinone.
\end{abstract}

Keywords: Nitisinone; High performance liquid chromatography; Method validation; Hereditary tyrosinemia type I

\section{Introduction}

Hereditary tyrosinaemia type 1 (HT-1) is a rare genetic disease caused by mutations in the gene for the enzyme fumarylacetoacetase. It usually presents with liver failure however it can be manifest as chronic liver disease. It is considered that there is a significant lifetime risk of developing hepatocellular carcinoma. Before the development of liver transplantation, most of the patients died in childhood (McKiernan, 2006).

Nitisinone (NTBC) is a reversible inhibitor of 4hydroxyphenylpyruvate dioxygenase and an active substance in the orphan drug used for the treatment of hereditary tyrosinemia type I (De Laetet al., 2013). The chemical name of nitisinone is 2-(2-nitro-4trifluoromethyl benzoyl)-1,3-cyclohexanedione (Fig. 1), with empirical formula $\mathrm{C}_{14} \mathrm{H}_{10} \mathrm{~F}_{3} \mathrm{NO}_{5}$, and molecular weight is $329.228 \mathrm{~g} / \mathrm{mol}$.

\footnotetext{
* zhaxhijaha@gmail.com
} 

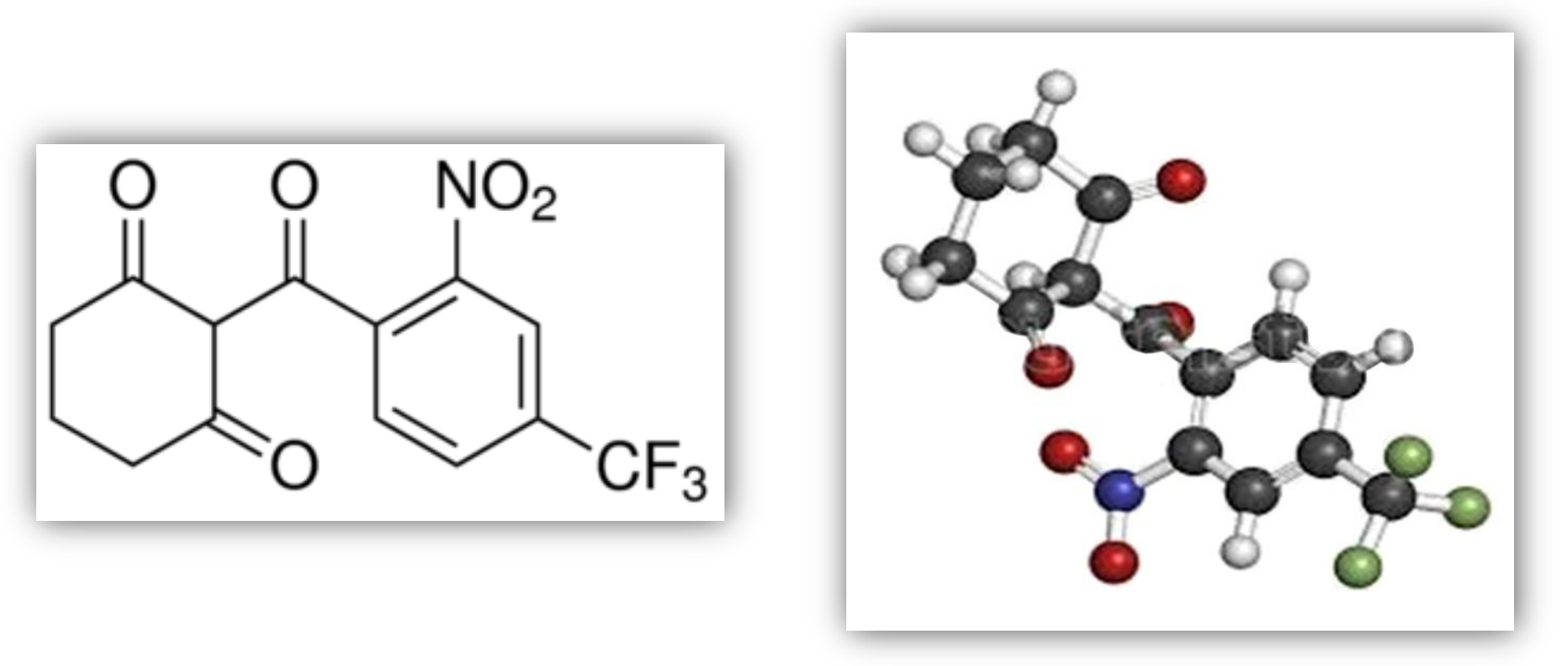

Fig. 1. Structure of nitisinone (accessed from https://www.picswe.com/pics/ hereditary-tyrosinemia-c7.htmL)

Nitisinone appears as off-white to yellowish nonhygroscopic fine crystalline powder. It is practically insoluble in water, freely soluble in dichloromethane, sparingly soluble in ethyl alcohol. Furthermore, NTBC is slightly soluble in isopropyl alcohol and $70 \%$ aqueous isopropyl alcohol and in $\mathrm{pH} 6.8$ phosphate buffer, very slightly soluble in $\mathrm{pH} 4.5$ acetate buffer and practically insoluble at $\mathrm{pH}$ 1.1. Solubility in acidified aqueous media depends on the acid counter ion. Solubility increases with increasing $\mathrm{Ph}$. Its pKa was found to be around 10. NTBC is achiral and does not show polymorphism (AktugluZeybek and Zubarioglu, 2017).

The innovator product containing NTBC active substance (Orfadin ${ }^{\mathbb{B}} 2 \mathrm{mg}, 5 \mathrm{mg}, 10 \mathrm{mg}$ and $20 \mathrm{mg}$ hard capsules), was approved for treatment of tyrosinemia, by the FDA and the EMA, on 21.02.2002 and 21.02.2005, respectively. In the treatment of hereditary tyrosinemia Type I, NTBC, a 4-hydroxyphenylpyruvate dioxygenase inhibitor, is recommended to be used in combination with limiting dietary tyrosine and phenylalanine intake (Lock et al., 2014).

NTBC has transformed the natural history of tyrosinaemia. The studies showed that liver failure is controlled in $90 \%$ of patients, those with chronic liver disease improve and nonhepatic manifestations are abolished. Furthermore, NTBCis well tolerated and has few adverse effects other than a predictable rise in plasma tyrosine levels (McKiernan, 2006).

There are only a small number of articles published on the determination of NTBC in pharmaceuticals and biological samples (Bielenstein et al., 1999; Hallet al., 2001). Capillary electrophoresis (Cansever et al., 2010) and LC-MS/MS methods (Davit-Spraul et al., 2012; Herebian et al., 2009; La Marca et al., 2011; Prieto et al.,
2011; Sander et al., 2011) have been reported for the determination of NTBC in biological fluids. Recently, Souri et al. (2015) developed a stability-indicating HPLC method for the determination of NTBC in capsules. Additionally, it should be noted that there is still no pharmacopeial monograph for nitisinone.

Therefore, our aim was to develop a simple and accurate RP-HPLC method with UV detection for determination of nitisinone in pharmaceuticals, without long steps of sample preparation and with adequate sensitivity for routine analysis in quality control laboratories, for stability studies, as well as for the evaluation of potentially counterfeit NTBC products.

\section{Materials and methods}

\section{Chemical and reagents}

Commercially available samples, hard capsules containing $5 \mathrm{mg}$ or $10 \mathrm{mg}$ nitisinone were used in this study. NTBC standard substance was provided by Ulkar Kimya Sanayii ve Ticaret A.Ş. (Turkey). HPLC-grade acetonitrile was purchased from Merck (Darmstadt, Germany). Double-distilled water was used to prepare mobile phase solutions.

\section{HPLC instrumentation and conditions}

HPLC analyses were performed using an Agilent Technologies chromatographic system (Hewlett Packard, Avondale, USA) consisting of a Model 1200 Series SL pump with a Model Agilent series G-1315C DAD detector and a Model Agilent 1200 series G-1329B ALS auto 
sampler. Data analyses were done using Agilent Technologies HPLC 1100 software. The chromatographic separation was achieved on a reversed-phase column Purospher STAR ${ }^{\circledR}$ RP-8 end-capped (150 x 4.6 mm i.d., particle size $5 \mu \mathrm{m}$ ), at the temperature of $25{ }^{\circ} \mathrm{C}$. The mobile phase consisted of a mixture of acetonitrile and water acidified with o-phosphoric acid (pH 3.0), 65:35 $(V / V)$, filtered through $0.45 \mu \mathrm{m}$ nylon filter. The flow rate was kept at $1 \mathrm{~mL} / \mathrm{min}$. Wavelength was selected by scanning a standard solution of NTBC over 200-400 nm using Model Lambda 12 (Perkin Elmer) UV-visible spectrophotometer. The wavelength of $272 \mathrm{~nm}$ was chosen for detection of NTBC. The injection volume was $10 \mu \mathrm{L}$.

\section{Preparation of solutions}

A stock solution of NTBC was prepared by dissolving about $1.0 \mathrm{mg}$ of the NTBC standard substance (accurately weighed on the analytical balance with readability to $0.01 \mathrm{mg}$ ( 5 decimal places)) in acetonitrile and diluting with the same solvent up to $10 \mathrm{~mL}$. Working standard solution (target concentration of $0.1 \mathrm{mg} / \mathrm{mL}$ ) was prepared by dilution of the stock standard solution with the same solvent.

For evaluation of linearity, seven aliquots of the stock solution were appropriately diluted with the same solvent to obtain solutions of NTBC in concentration range of $0.00844-0.422 \mathrm{mg} / \mathrm{mL}$.

Twenty capsules were weighed accurately on the analytical balance with readability to $0.01 \mathrm{mg}$ and the net content of each capsule was calculated. Capsule powder equivalent to $10 \mathrm{mg}$ NTBC was accurately weighed and transferred to a $100 \mathrm{~mL}$ volumetric flask with addition of about $70 \mathrm{~mL}$ acetonitrile. The mixture was sonicated in an ultrasonic bath for $15 \mathrm{~min}$. and volume was made up to the mark with the same solvent (target concentration of $0.1 \mathrm{mg} / \mathrm{mL}$ NTBC).

All solvents and solutions for HPLC analysis were filtered through a membrane filter $(0.45 \mu \mathrm{m}$ pore size $)$ and vacuum degassed before use.

\section{Method validation}

The proposed method was validated according to the ICH Harmonized Tripartite Guideline; Validation of Analytical Procedures: Text and Methodology Q2(R1) (ICH, 2005). The parameters used to validate the analytical method were system suitability, specificity, linearity, range, accuracy, precision, detection limit (DL) and quantitation limit (QL).

\section{System suitability}

System suitability testing is considered as an integral part of the chromatographic method validation procedure and is regularly performed in order to check on-going performance of the chromatographic system. We estimated the system repeatability by 6 consecutive injections of standard solution at $100 \%$ of the test Макед. фарм. билт., 65 (2) 57 - 65 (2019) concentration $(0.1 \mathrm{mg} / \mathrm{mL}$ NTBC $)$. The system suitability parameters were calculated as described in the United States Pharmacopoeia (General Chapter <1225>; <621>). As acceptance criteria we used the limits recommended in the FDA guideline on "Validation of Chromatographic Methods" (1994).

\section{Specificity}

Specificity is defined as the ability of the analytical procedure to assess unequivocally the analyte in the presence of components which may be expected to be present (impurities, degradants, matrix, etc.). In the case of assay (determination of content or potency), specificity is also the ability of the analytical procedure to provide an exact result which allows an accurate statement on the content or potency of the analyte in a sample (ICH, 2005). The specificity of the proposed method was demonstrated by spiking the capsule formulations with known quantities of NTBC standard, then checking for interference with the placebo.

\section{Linearity and range}

For linearity evaluation, a calibration curve was obtained at 7 concentration levels of NTBC standard solutions $(0.00844-0.422 \mathrm{mg} / \mathrm{mL})$. The solutions $(10$ $\mu \mathrm{L})$ were injected in triplicate into a chromatographic system using the proposed chromatographic conditions. Then, the peak area and concentrations were subjected to a least square regression analysis to calculate calibration equation and determination coefficient.

\section{Precision}

The precision of the proposed analytical procedure (intra-assay precision) was assessed using six determinations of sample solutions at $100 \%$ of the test concentration $(0.1 \mathrm{mg} / \mathrm{mL} \mathrm{NTBC})$ on the same day, by the same analyst and using the same equipment. The intermediate precision of the analytical procedure was assessed analyzing the same sample solutions on three consecutive days. The precision was expressed as the relative standard deviation of series of measurements.

\section{Detection limit and quantitation Limit}

Detection limit (DL) and quantitation limit (QL) of the proposed RP-HPLC method were determined by injecting low concentrations of the standard solutions (0.00844 - $0.0422 \mathrm{mg} / \mathrm{mL})$. We calculated DL and QL according to ICH guidelines (ICH, 2005) applying a signal-to-noise ratio approach. We measured signals from samples with known low concentrations of NTBC with those of blank samples and then we established the minimum concentration at which NTBC can be reliably detected. A signal-to-noise ratio between 3.3:1 was considered acceptable for estimation of the detection limit, while a typical signal-to-noise ratio for quantitation limit was 10:1. 

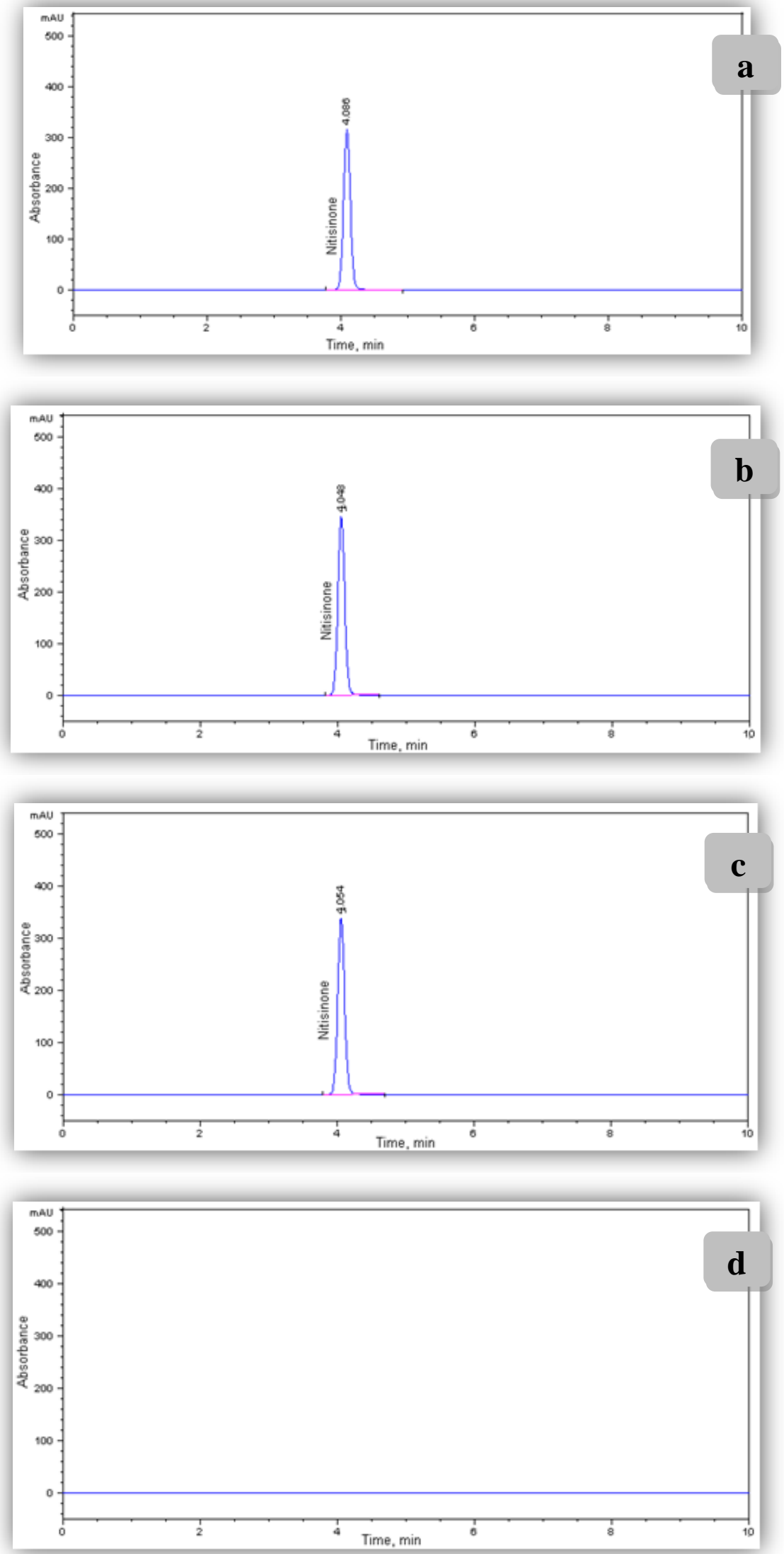

Fig. 3. Typical chromatograms of: nitisinone standard solution (a); Nitisinone capsule $5 \mathrm{mg}$ sample solution (b); Nitisinone capsule $10 \mathrm{mg}$ sample solution (c); blank solution (d) 


\section{Accuracy}

To study the accuracy of the proposed analytical method, recovery tests were conducted using the standard addition method. Hence, known amounts of NTBC standard substance were added to capsules and the resulting mixtures were analyzed by the proposed methods. We spiked placebo samples with NTBC standard solution at three concentration levels (0.08262 $0.12141 \mathrm{mg} / \mathrm{mL}$ ). The percent of recovery was calculated as follows:

$$
\text { Recovery }(\%)=[[\mathrm{C} v-\mathrm{C} u] / \mathrm{C} a] \times 100
$$

where $\mathrm{C} v$ is the total amount of NTBC measured after standard addition, $\mathrm{C} u$ the amount of NTBC in the drug formulation, and $\mathrm{C} a$ the amount of NTBC added to the formulation.

\section{Results and discussion}

\section{Method development}

During the method development, we applied isocratic HPLC system with safe mobile phase (not highly saline, $\mathrm{pH}$ more than 2.5 , and acceptable flow rate). A variety of mobile phases and different columns were investigated in the development of a HPLC method for analysis of NTBC. These included: acetonitrile - water, 50:50 ( V/V), acetonitrile - water, 70:30 ( V/V), acetonitrile - water acidified with o-phosphoric acid with $\mathrm{pH}$ adjusted to 3.0, 65:35 (V/V) and different columns (RP-C8, and RP-C18) from different manufacturers with different lengths (25.0, $15.0,12.5$, and $10.0 \mathrm{~cm}$ ) and constant internal diameter of $4.6 \mathrm{~mm}$. The suitability of the mobile phase was decided on a basis of the sensitivity of the assay, ease of preparation, and use of readily available cost-effective solvents. Thus, the mobile phase consisted of a mixture of acetonitrile and water acidified with o-phosphoric acid with $\mathrm{pH}$ adjusted to 3.0, 65:35 ( V/V) and the reversedphase column Purospher STAR ${ }^{\circledR}$ RP-8 end-capped $(150$ x $4.6 \mathrm{~mm}$ i.d., particle size $5 \mu \mathrm{m}$ ), was found optimal for isocratic determination of NTBC in pharmaceuticals. The wavelength was selected by scanning the standard solution of NTBC over 200-400 nm and the wavelength of $272 \mathrm{~nm}$ was chosen for detection of NTBC (Fig. 2).

NTBC was identified based on the retention time as compared with the NTBC standard. Furthermore, the identification NTBC was confirmed by adding standard to sample solution prior to analysis, which resulted in an increased peak area proportionally to the added amount of NTBC. The average retention time of the NTBC was approximately $4.03 \mathrm{~min}$ at a flow rate of $1 \mathrm{~mL} / \mathrm{min}$. The NTBC was determined in a short time as a sharp single peak. About $10 \mathrm{~min}$ was required for each analysis. No interference from excipients and potential degradation products was observed (Fig. 3).

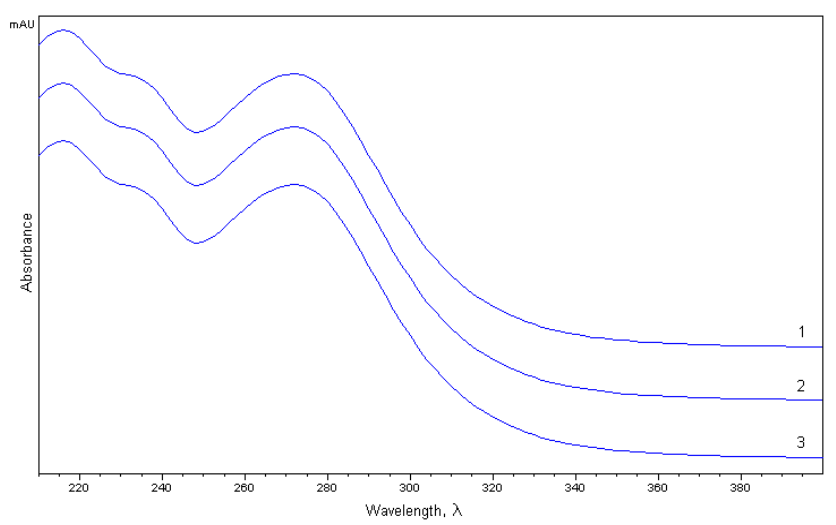

Fig. 2. UV spectra of: nitisinone standard solution (1); sample solution of Nitisinone capsule 5 mg (2); sample solution of Nitisinone capsule $10 \mathrm{mg}(3)$.

\section{Method validation}

System suitability - The results of system suitability test (Table 1) were found within the acceptable range proving that the chromatographic system was suitable for NTBC determination. Acceptable peak symmetry (tailing factor) and retention time were observed without any interference from capsule excipients or degradation products. System suitability parameters were obtained from six replicate injections.

Table 1. Results of system suitability test

\begin{tabular}{lcc}
\hline \hline Parameter & Results & Parameter Limit \\
\hline RSD of retention time & $0.30 \%$ & $<1 \%$ \\
RSD of peak area & $0.38 \%$ & $<1 \%$ \\
Capacity factor k' & 2.30 & $>2$ \\
Tailing factor T & 0.96 & $<2$ \\
Theoretical plate & 7613.25 & $>2000$ \\
\hline
\end{tabular}

Specificity - In the specificity study, standard solution of NTBC and sample solutions containing NTBC were injected and a single peak was obtained for NTBC, which indicates that there was no interference from the excipients used or from the mobile phase. Representative chromatograms of a NTBC standard solution, sample solutions and a blank solution are presented in Fig. 3 (a, $b, c, d)$. 
Linearity and range - In the present study, linearity was studied in the concentration range of $0.00844-0.422$ $\mathrm{mg} / \mathrm{mL}$ NTBC and the following regression equation was found by plotting the peak area $(y)$ expressed in mAU versus the NTBC concentration $(x)$ expressed in $\mathrm{mg} / \mathrm{mL}: y$ $=15165 x-23.019\left(r^{2}=0.9999\right)$. The determination coefficient $\left(r^{2}\right)$ demonstrates the excellent relationship between the peak area and the concentration of NTBC. The regression lines were not significantly different from a curve passing through the origin $y=$ a $x$. ( $P$-value of the slope $>0.05)$. (Table 2).

Table 2. Characteristics of the linear regression analysis

\begin{tabular}{|c|c|}
\hline Parameter & NTBC API $^{\mathrm{a}}$ \\
\hline Linearity range $(\mu \mathrm{g} / \mathrm{mL})$ & $8.44-42.2$ \\
\hline Slope & 15165 \\
\hline Intercept & -23.019 \\
\hline Determination coefficient $\left(\mathrm{r}^{2}\right)$ & 0,9999 \\
\hline $\mathrm{SE}^{\mathrm{b}}$ of the intercept & 11.392 \\
\hline SE of the slope & 52.839 \\
\hline$P$-value of the slope & 0,099 \\
\hline
\end{tabular}

Precision and accuracy - The variation in the results obtained within a day $(\mathrm{RSD}=0.29 \%$, and $\mathrm{RSD}=0.50 \%$, for Nitisinone $5 \mathrm{mg}$ capsule, and $10 \mathrm{mg}$ capsule, respectively) and day to day variations $(\mathrm{RSD}=0.43 \%)$ for NTBC determination was very low $(\leq 2 \%)$, thus confirming the precision of the method. The statistical data is shown in Table 3.

The average recovery of the added amounts of NTBC at three concentration levels was $99.22 \% \pm 0.86 \%$ $(n=9)$. Mean recovery (Table 4$)$ was between $98.42 \%$ and $100.76 \%$ indicating that the proposed method was sufficiently accurate for the determination of NTBC in pharmaceutical formulation.

Detection limit and quantitation limit - The limit of detection (DL) and limit of quantitation (QL) were 0.0486 $\mu \mathrm{g} / \mathrm{mL}$ and $0.147 \mu \mathrm{g} / \mathrm{mL}$, respectively. The proposed RPHPLC method was demonstrated to be sensitive for performing the determination of NTBC during the product release and throughout the shelf life of pharmaceuticals containing nitisinone active substance.

\section{Method applications}

The validated method was applied for determination of NTBC in commercially available Nitisinone $5 \mathrm{mg}$ and $10 \mathrm{mg}$ hard capsules. Fig. 2 illustrates typical HPLC chromatograms obtained from a standard solution, Nitisinone $5 \mathrm{mg}$ and $10 \mathrm{mg}$ hard capsules sample solutions, and blank solution, respectively. The results of the assay ( $n=20$ capsules) undertaken yielded $106.63 \%$ $(\mathrm{RSD}=0.29 \%)$, and $107.33 \%(\mathrm{RSD}=0.50 \%)$ of label claim for NTBC in Nitisinone $5 \mathrm{mg}$ capsule, and $10 \mathrm{mg}$ capsule, respectively. The average retention time of nitisinone was approximately $4.03 \mathrm{~min}$. The results indicate that the method is specific for the analysis of nitisinone without interference from the excipients used to formulate and produce these capsules.

Table 3. Precision of the method

\begin{tabular}{|c|c|c|c|c|}
\hline Precision Parameter & & $\%$ of declared content $(X)$ & RSD (\%) & Bias (\%) \\
\hline & $5 \mathrm{mg}$ capsule & 106.63 & 0.29 & 6.63 \\
\hline \multirow[t]{3}{*}{ Intra-assay Precision ${ }^{a}$} & 10 mg capsule & 107.33 & 0.50 & 7.25 \\
\hline & Day 1 & 106.63 & 0.29 & 6.63 \\
\hline & Day 2 & 105.20 & 0.74 & 5.20 \\
\hline \multirow[t]{2}{*}{ Intermediate Precision ${ }^{\mathrm{a}, \mathrm{b}}$} & Day 3 & 104.77 & 0.26 & 4.77 \\
\hline & $\bar{X}$ & 105.53 & 0.43 & 5.53 \\
\hline
\end{tabular}


Table 4. Accuracy of the method

Theoretical amount

$(\mu \mathrm{g} / \mathrm{mL}) \quad$ Amount found $(\mu \mathrm{g} / \mathrm{mL}) \quad$ Recovery $(\%) \quad$ Bias $(\%) \quad$ Mean Recovery \pm RSD $(\%)^{\mathrm{a}}$

\begin{tabular}{ccccc}
\hline 81.76 & 98.98 & -1.02 & \\
82.62 & 81.13 & 98.23 & -1.77 & $98,42 \pm 0,49$ \\
\hline 108.48 & 106.95 & 98.06 & -1.94 & \\
& 106.6 & 98.59 & -1.41 & $98,47 \pm 0,17$ \\
\hline 106.91 & 98.27 & -1.73 & \\
\hline 121.41 & 124.1 & 98.55 & -1.45 & $100,76 \pm 1,91$ \\
& 119.71 & 102.21 & 2,21 & \\
& 123.2 & 98.6 & -1.40 & \\
\hline & $\bar{X}$ & 101.48 & 1.48 & $99,22 \pm 0,86$ \\
\hline
\end{tabular}

${ }^{\mathrm{a}} n=3$ determinations

\section{Conclusion}

The proposed RP-HPLC method allows a simple, accurate, precise and rapid determination of nitisinone API in pharmaceuticals. The advantages of the method include simple sample treatment with sonication of small amounts of sample at ambient temperature, good precision (RSD $<2 \%$ ) and high recovery (greater than 99\%). Additionally, simple preparation reduces the laboratory expenses, while retaining enough sensitivity for determination of NTBC in commercially available pharmaceutical preparations. The proposed method could be applied for routine analysis in quality control laboratories, in stability studies as well as for the evaluation of potentially counterfeit Nitisinone capsules.

\section{References}

Aktuglu-Zeybek, A.C., \& Zubarioglu, T., 2017. Nitisinone: A review. Orphan Drugs: Research and Reviews 7, 25. Available at: https://doi.org/10.2147/ODRR.S92995.

Bielenstein, M., Astner, L., Ekberg, S., 1999. Determination of 2-(2-nitro-4-trifluoromethylbenzoyl)-1, 3-cyclohexanedione in plasma by direct injection into a coupled column liquid chromatographic system. J. Chromatogr. B Biomed. Sci. Appl. 730(2), 177-182. Available at: https://doi.org/10.1016/s0378-4347(99)00199-1.

Cansever, M.Ş., Aktuğlu-Zeybek, A.Ç., \& Erim, F.B., 2010.
Determination of NTBC in serum samples from patients with hereditary tyrosinemia type I by capillary electrophoresis. Talanta 80(5), 1846-1848. Available at: https://doi.org/10.1016/j.talanta.2009.10.032.

Davit-Spraul, A., Romdhane, H., Poggi-Bach, J., 2012. Simple and Fast Quantification of Nitisone (NTBC) using Liquid Chromatography-Tandem Mass Spectrometry Method in Plasma of Tyrosinemia Type 1 Patients. J. Chromatogr. Sci. 50(5), 446-449. Available at: https://doi.org/10.1093/chromsci/bms022.

De Laet, C., Dionisi-Vici, C., Leonard, J.V., McKiernan, P., Mitchell, G., Monti, L., de Baulny, H.O., Pintos-Morell, G., Spiekerkötter, U., 2013. Recommendations for the management of tyrosinemia type 1. Orphanet J. Rare Dis. $8(1), 8$.

Hall, M.G., Wilks, M.F., Provan, W.M., Eksborg, S., Lumholtz, B., 2001. Pharmacokinetics and pharmacodynamics of NTBC (2-(2-nitro-4-fluoromethylbenzoyl)-1, 3-cyclohexanedione) and mesotrione, inhibitors of 4-hydroxyphenyl pyruvate dioxygenase (HPPD) following a single dose to healthy male volunteers. Br. J. Clin. Pharmacol. 52(2), 169177. Available at: https://doi.org/10.1046/j.0306-5251.2001.01421.x.

Herebian, D., Spiekerkötter, U., Lamshöft, M., Thimm, E., Laryea, M., Mayatepek, E., 2009. Liquid chromatography tandem mass spectrometry method for the quantitation of NTBC (2-(nitro-4-trifluoromethylbenzoyl) 1, 3cyclohexanedione) in plasma of tyrosinemia type 1 patients. J. Chromatogr. B Analyt. Technol. Biomed. Life Sci. 877(14-15), 1453-1459. Available at: https://doi.org/10.1016/j.jchromb.2009.03.014.

ICH Q2R1: Validation of Analytical Procedures: Text and 
Methodology. Proceeding of the International Conference on Harmonization of Technical Requirements for the Registration of Drugs for Human Use, Geneva, Switzerland, 1996. Available at:

https://www.ema.europa.eu/en/documents/scientificguideline/ich-q-2-r1-validation-analytical-procedures-textmethodology-step-5_en.pdf.

La Marca, G., Malvagia, S., Materazzi, S., Della Bona, M.L., Boenzi, S., Martinelli, D., Dionisi-Vici, C., 2011. LCMS/MS method for simultaneous determination on a dried blood spot of multiple analytes relevant for treatment monitoring in patients with tyrosinemia type I. Anal. Chem. 84(2), 1184-1188. Available at: https://doi.org/10.1021/ac202695h.

Lock, E., Ranganath, L R., Timmis, O., 2014. The role of nitisinone in tyrosine pathway disorders. Curr. Rheumatol. Rep. 16(11), 457. Available at: https://doi.org/10.1007/s11926-014-0457-0.

McKiernan, P.J., 2006. Nitisinone in the treatment of hereditary tyrosinemia type 1. Drugs 66(6), 743-750. Available at: https://doi.org/10.2165/00003495-200666060-00002.

Prieto, J.A., Andrade, F., Lage, S., Aldámiz-Echevarría, L., 2011. Comparison of plasma and dry blood spots as samples for the determination of nitisinone (NTBC) by high-performance liquid chromatography-tandem mass spectrometry. Study of the stability of the samples at different temperatures. J. Chromatogr. B Analyt. Technol. Biomed. Life Sci. 879(11-12), 671-676. Available at: https://doi.org/10.1016/j.jchromb.2011.01.031.

Reviewer Guidance: Validation of Chromatographic Methods. 1994. Center for Drug Evaluation and Research. Food and Drug Administration. Washington, DC: Department of Health and Human Services.

Sander, J., Janzen, N., Terhardt, M., Sander, S., Gökcay, G., Demirkol, M., Ozer, I., Peter, M., Das, A.M., 2011. Monitoring tyrosinaemia type I: Blood spot test for nitisinone (NTBC). Clin. Chim. Acta. 412(1-2), 134-138. Available at: https://doi.org/10.1016/j.cca.2010.09.027.

Souri, E., Lahiji, F. R., Nourhashemi, T., Jalalizadeh, H., 2015. A stability indicating HPLC method for the determination of nitisinone in capsules. Indian J. Pharm. Sci. 77(3), 348. Available at: https://doi.org/10.4103/0250-474X.159674.

United States Pharmacopoeia - National Formulation (USP 32 - NF 27). 2009. General Chapter <1225>, Validation of Compendial Methods, United States Pharmacopoeial Convention Inc., Rockville, MD, USA.

United States Pharmacopoeia - National Formulation (USP 32 NF 27). 2009. General Chapter <621>, Chromatography, United StatesPharmacopoeial Convention Inc., Rockville, MD, USA.

\title{
Едноставен изократски реверзно-фазен HPLC метод за определување на нитисинон во фармацевтски препарати
}

\author{
Зана Мустафа ${ }^{1 *}$, Зорица Арсова-Сарафиновска ${ }^{1}$, Маја Шишовска $^{1}$, \\ Александра Грозданова ${ }^{2}$ \\ ${ }^{1}$ Институт за јавно здравје на Република Северна Македонија, ул. 50 Дивизија бр. 6, \\ 1000 Скопје, Република Северна Македонија \\ ${ }^{2}$ Институт за фармачевтска хемија, Фармацевтски факултет, \\ Универзитет „Св Кирил и Методиј“, Мајка Тереза 47, 1000 Скопје, \\ Република Северна Македонија
}

Клучни зборови: нитисон; течна хроматографија под висок притисок; валидација на метод; наследна тирозинемија тип 1

Нитисинон е реверзибилен инхибитор на ензимот 4-хидроксифенил-пируват-диоксигеназа и активна супстанција во лекот за ретки болести наменет за третман на наследна тирозинемија тип I, ретка болест предизвикана од мутации на генот за ензимот фумарилацетоацет хидролаза. Цел на нашата студија беше да се развие едноставен и точен реверзно-фазен HPLC метод за рутинско определување на нитисинон во комерцијално достапни дозирани фармацевтски форми. Хроматографското раздвојување беше постигнато со употреба на Purospher STAR ${ }^{\circledR}$ RP-8 реверзно-фазна колона (150 х $4.6 \mathrm{~mm}$ I.D., со големина на честички $\left.5 \mu \mathrm{m}\right)$, со мобилна фаза составена од ацетонитрил и вода (закиселена со о-фосфорна киселина до $\mathrm{pH} 3,0)$, во однос 65:35 ( $V / V)$, филтрирана преку најлонски филтер со големина на пори $0,45 \mu \mathrm{m}$. Елуирањето го изведовме со проток од 1 $\mathrm{mL} / \mathrm{min}$. Волуменот на инјектирање беше $10 \mu \mathrm{L}$. Апсорпцијата на примерокот ја измеривме со DAD детектор на бранова должина од $272 \mathrm{~nm}$. 
Методот го валидиравме со утврдување на параметрите: соодветност на системот, специфичност, линеарност, опсег, точност, прецизност, граница на детекција и граница на определување. Потоа, ја определивме содржината на нитинонон во комерцијално достапни капсули. Методот овозможува едноставно, точно, прецизно и брзо определување на нитисинон во фармацевтски препарати. Предностите на овој метод се: едноставна подготовка на примерокот, добра прецизност (RSD $\leq 2 \%)$ и добар аналитички принос $(\geq 99 \%)$. Предложениот метод може да се препорача за рутинска анализа во лабораториите за контрола на квалитет на лекови, во студии за стабилност, како и за испитување на потенцијално фалсификувани препарати кои содржат нитисинон. 
